\title{
Time Kill Kinetics Study of Commonly Used Disinfectants against Biofilm forming Pseudomonas aeruginosa in Federal Medical Centre, Umuahia-Nigeria
}

\author{
Agbo Ejiofor $\mathrm{C}^{1,2}$, Achi OK ${ }^{2}$, Nwachukwu E ${ }^{2}$, Obeta M Uchejeso ${ }^{3 *}$, Obiora E Okechukwu $^{1}$, Maduka \\ K Maduabuchi ${ }^{4}$, Oraekeyi Nkiruka $\mathrm{P}^{5}$ and Lote-Nwaru $\mathrm{IE}^{5}$ \\ ${ }^{1}$ Department of Medical Laboratory Services, Federal Medical Centre, Umuahia-Nigeria
}

${ }^{2}$ Department of Microbiology, Michael Okpara University of Agriculture, Umudike-Nigeria

${ }^{3}$ Department of Chemical Pathology, Federal School of Medical Laboratory Science, Jos-Nigeria

${ }^{4}$ Good Laboratory Practice (Technical \&Logistics) Hospital Management Board FCDA, Abuja-Nigeria

${ }^{5}$ Department of Medical Microbiology, Federal School of Medical Laboratory Science, Jos-Nigeria

*Corresponding author: Obeta M Uchejeso, Department of Chemical Pathology, Federal School of Medical Laboratory Science, JosNigeria.

To Cite This Article: Obeta M Uchejeso, Time Kill Kinetics Study of Commonly Used Disinfectants against Biofilm forming Pseudomonas aeruginosa in Federal Medical Centre, Umuahia-Nigeria. 2020 - 7(3). AJBSR.MS.ID.001155. DOI: 10.34297/AJBSR.2020.07.001155.

Received: 盘 January 22, 2020; Published: 製 February 18, 2020

\section{Abstract}

Background: Noncritical surfaces in hospital environment can serve as reservoirs of pathogenic bacteria. Among these pathogens, biofilms forming Pseudomonas species are among the leading cause of nosocomial infections frequently involved in hospital environment. Pseudomonas aeruginosa, an opportunistic and biofilm forming pathogen, is the cause of a wide range of hospital acquired infections and can survive for several days on inanimate objects and surfaces in clinical settings. These survival properties most likely play a significant role in its infection dissemination and antibiotic resistance in the hospital environment where hospital cleaners frequently use disinfectants to clean without recourse to concentration or frequency of the cleaning.

Aim of study: To determine the antibacterial activities of commonly used disinfectants-Izal (Phenolic Compound), Savlon (Chlorhexidine cetrimide), and bleach (Hypochlorite) involving Time kill kinetics studies in Federal Medical Centre, Umuahia on biofilm forming Pseudomonas aeruginosa.

Study volunteers and methods: Four hundred and fifty positive (450) samples from noncritical surfaces of six selected wards of the hospital from 1314 samples. Bacterial analysis was performed by using conventional microbiological techniques, biochemical tests and the Microbact $24 \mathrm{E}$ assay. The time- kill kinetics antibacterial study of antiseptics was done according to standard guide for assessment of antimicrobial activity using time-kill kinetics procedure of Antimicrobial Susceptibility Testing Method and Microbial population at the initiation and completion was determined by spectrometric and plate count methods at interval of $2 \mathrm{~h}$ for $24 \mathrm{~h}$.

Result: Pseudomonas aeruginosa resisted the disinfectants after $4 \mathrm{~h}$ of initiation time/application. The $2 \mathrm{mg} / \mathrm{ml}$ concentration of Izal achieved total lethality after $12 \mathrm{~h}$; Savlon, bacteriostatic effect was $8 \mathrm{~h}$ (i.e. from $3.0 \times 10^{6}+5.774$ to $3.02 \times 10^{6}+5.773 \mathrm{~b}$ and $4.2 \times 10^{6}+5.774 \mathrm{a}$ to $3.21 \times 10^{6}+5.773 \mathrm{e}$ respectively) but $2 \mathrm{mg} / \mathrm{ml}$ of Savlon showed total lethality (bactericidal effect) after $10 \mathrm{~h}$ from initiation time (i.e. 4.5x106+5.774a to $2.2 \times 105+5.773 \mathrm{~d}$ ) At concentration of $2 \mathrm{mg} / \mathrm{ml}$, Bleach showed outright lethality after $4 \mathrm{~h}$ of initiation time (i.e. from $4.2 \times 10^{6}+5.774 \mathrm{a}$ to $3.90 \times 10^{5}+5.775$ ) after which there remained no organism i.e. total eradication throughout the $24 \mathrm{~h}$ of incubation period.

Conclusion: $2 \mathrm{mg} / \mathrm{ml}$ is the best concentration for Pseudomonas aeruginosa lethality to be achieved using Izal, Savlon and Bleach as disinfectants in FMC Umuahia. Bleach is the most efficacious disinfectant in use in Federal Medical Center Umuahia having demonstrated maximum lethality (maximum bactericidal effect) at a shorter time of $4 \mathrm{~h}$ than Savlon, $8 \mathrm{~h}$ and Izal, $12 \mathrm{~h}$ though there was steady sustenance of bactericidal and bacteriostatic activity by Izal for a very long period compared to others.

Keywords: Time kill kinetics; Disinfectants; Pseudomonas aeruginosa; Medical Centre 


\section{Introduction}

The potential for a contaminated environmental surfaces to contribute to transmission of healthcare- associated pathogens depends on a number of factors including the ability of the pathogen to remain viable on a variety of dry environmental surfaces, frequency with which the contaminated surfaces are regularly touched by patients and healthcare workers and whether or not such contaminations are sufficiently high to result in transmission to patients. Noncritical surfaces are at the center of such contamination and thus serve as important route of transmission of pathogens [1]. Transmission from healthcare worker`s hand or gloves has been documented in some studies [2]. There could be direct transmission from contaminated noncritical surfaces to patients [3]. Elimination of the environmental source of contamination reduced transmission of several outbreaks [4].

So far there is no direct study to demonstrate that environmental contaminants are liable for Health Associate Infections (HAIs), but there is increasing evidence from a number of studies to suggest that in the hospital environments, microbial transfer between surfaces causes health healthcare associated infections in humans [5]. Surfaces frequently touched by hands pose a notable risk in this regard. Therefore, transfer of microbial contamination from hand contact on contaminated surfaces of noncritical equipment or other inanimate objects or to patients, represents direct mode of transmission $[6,7]$. Hands may acquire and transfer microorganism to other inanimate objects or patients by touching contaminated noncritical equipment [7] indicating that hospital environment provides a setting, for the development and dissemination of infections.

According to World Health Organization data, in every 100 hospitalized patients, between 7 and 10 are expected to contract at least one healthcare associated infection [8]. Disinfectants used on noncritical surfaces in the hospitals are both broad-spectrum and multi targeted biocidal compounds [9]. They are also often used as environmental disinfectants for medical devices [10]. These include alcohols, chlorine, and chlorine compounds, formaldehyde, glutaraldehyde, orthophthalaldehyde, hydrogen peroxide, iodophors, peracetic acid, phenolic and quaternary ammonium compound, but their killing efficacy, especially against biofilms, is questionable [6].

The European Standard of 24th April, 1998 (CE/8/98), defines disinfectant products as standard substances or preparations that contain one or more active ingredients, presented to the user in their final form and whose function is to destroy, stop the growth, make harmless, avoid or control by any means, the action of a pathogenic organism by a biological or chemical process. The use of disinfectants in biofilm control is well accepted and very common. Although disinfectants are used for the reduction of number of microorganisms, their simple use does not necessarily reduce the biofilm formation rate. It is essential to use the correct concentration and amount of the disinfectants, with the correct frequency. The incorrect application is expensive and leads to unwanted results [11].

Disinfectants are used extensively in hospitals and healthcare settings for a variety of topical and hard surface applications. In particular, they are essential part of infection control practices and aid in the prevention of nosocomial infections in general [12]. Disinfectants resistance is an emerging issue that is now attracting interest [13]. The selection, use and control of the effectiveness of disinfectants have been emphasized, since environmental surfaces and noncritical equipment can serve as vehicles for infectious agents' transmission to susceptible hosts associated with the hospital setting [12]. Although different strategies are designed for the control of antimicrobial drugs and disinfectants resistance, most countries to date have focused on two main strategies involving the appropriate and prudent use of antimicrobial drugs and disinfectants in hospitals and good infection control practices in hospitals and the community [14].

There could be surface contamination following inadequate cleaning and disinfection especially the failure to use the recommended guidelines for cleaning healthcare equipment $[15,16]$. Surfaces in hospital rooms are often poorly cleaned during terminal cleaning. Although methods of assessing the adequacy of cleaning varied (i.e., visibly clean, ATPase, fluorescent dye, aerobic plate counts), less than $50 \%$ of room surfaces are clean [17]. Similar deficiencies have been reported for cleaning and disinfection of portable medical equipment between patients [18]. Given the deficiencies demonstrated in terminal cleaning, it is not surprising that many hospital surfaces remain contaminated with important nosocomial pathogens.

The most commonly used surface disinfectants in hospitals have been phenols and quaternary ammonium compounds. Hypochlorites often have been used to disinfect surfaces in rooms of patients previously infected with some hard-to-treat nosocomial pathogen [19]. Multiple surface disinfectants are now US Environmental Protection Agency (EPA)-registered just as many of them are equally registered by Nigerian NAFDAC (National Agency for Food and Drug Administration and Control ) as effective against Pseudomonas aeruginosa, $C$. difficile etc.; most containing sodium hypochlorite but several other germicides have also been registered namely ethaneperoxoic acid/hydrogen peroxide, silver and tetraacetylethylenediamine. Hospitalization in a room in which the previous patient had been colonized or infected with MRSA, VRE, C. difficile, multidrug-resistant Acinetobacter spp. or multidrug-resistant Pseudomonas aeruginosa has been shown to be a risk factor for colonization or infection with the same pathogen for the next patient admitted to the room [20].

Chemical and mechanical treatment has synergistic effect as both play important roles in bacterial removal and control. Sodium hypochlorite, Hydrogen peroxide, Ozone, Sodium hypochlorite, Izal 
and Peracetic acid are the major disinfectants commonly used in Hospital environments [21] like the Federal Medical Centre Umuahia. Sodium hypochlorite $(\mathrm{NaClO})$ is more effective at low $\mathrm{pH}$ than alkaline pH environments [22]. It's efficacy in eliminating microbial biofilm has been proven against microorganisms like Pseudomonas aeruginosa, Staphylococcus aureus, Prevotella intermedius, Peptostreptococcus miros, Streptococcus intermedius, Fusobacterium nucleatum and Enterococcus faecalis when compared to other disinfectants [23]. Hydrogen peroxide $\left(\mathrm{H}_{2} \mathrm{O}_{2}\right)$, is one of the widely used disinfectant due to its high oxidizing capacity based on the production of free radicals which affects the biofilm matrix and has been found to be efficient against most microbial biofilms [24]. Many studies have shown its efficiency as a disinfectant of choice against biofilms [25]. It is a safe solution which does not cause allergic reactions. It can also be used at a high concentration without affecting the surface materials adversely [26].

Ozone, on the other hand is a bluish gas formed as a result of oxygen atoms exposed to high-voltage electric discharge. The mode of action of ozone antiseptics is the disruption or breakdown of cell envelope leading to the leakage of cell contents. Cell lysis as a result of using ozone disinfectant is a faster inactivation mechanism than that of other antimicrobial agents where permeation through the cell membrane is indispensable in order to effectively inactivate the microbe. Due to this mechanism, it is speculated that the use of ozone cannot lead to microbial resistance [27]. The disinfection and removal by ozone water of Pseudomonas flouresens and Pseudomonas aeruginosa biofilms showed that by forming biofilms, the resistance of these microorganisms to ozone can increase by 3000 times respectively [28]. The reason behind the resistance is due to the reaction between the ozone and the biofilm matrix introduced into the environment by the bacteria. However, less than $1 \%$ of such cells survive after such interaction or treatment with ozone.

Peracetic acid is a result of the reaction between hydrogen peroxide and acetic acid or by the oxidation of acetaldehyde. The mixture has a strong odour and low pH (2.8) and is usually produced in concentration between $5 \%$ and $15 \%$. It is an ideal antimicrobial agent due to its extreme oxidizing capacity. Furthermore, it cannot be deactivated by catalase and peroxidase which are enzymes that degrades $\mathrm{H}_{2} \mathrm{O}_{2}$. This agent also decomposes into safe and extremely environmentally friendly residues (acetic acid and Hydrogen peroxide), hence it can be applied without rinsing and its efficiency is not affected by protein residues $[29,30]$.

Increases in the incidence of multidrug-resistant bacteria like Pseudomonas aeruginosa and its transmission in the hospital environments has increased the quest to study the effectiveness of antiseptics and disinfectants with the time of actions within 24 hours to kill or hinder transmission from hospital tools of staff to others.

\section{Materials and Methods}

This study was conducted at 800 beds capacity Federal Medical Center, Umuahia in Abia State after obtaining management and ethical approvals. The study used common disinfectants (Izal, Savlon \& Bleach) on Pseudomonas aeruginosa isolated from hospital equipment and surfaces 2-3 colonies of $20 \mathrm{~h}$ growth of the Pseudomonas aeruginosa on Muller Hinton agar were suspended in $50 \mathrm{ml}$ prewarmed $\left(37^{\circ} \mathrm{C}\right)$ Mueller Hinton broth. The suspension was incubated overnight at $37^{\circ} \mathrm{C}$, diluted 1 in 250 in the same pre-warmed medium and incubated in water bath with agitation (50 rpm). The absorbance of the culture was monitored with a spectrophotometer (6405 Jenway, Barloworld Scientific Ltd. Dunmow, Essex CMB $3 \mathrm{LB}$ ), using a wavelength $450 \mathrm{~nm}$ and $19 \mathrm{~mm}$ diameter spectrophotometer tubes until absorbance of 0.1 was reached.

The time- kill kinetics antibacterial study of antiseptics was done according to standard guide for assessment of antimicrobial activity using time-kill kinetics procedure of Antimicrobial Susceptibility Testing Method [31].

Microbial population at the initiation and completion was determined by spectrometric and plate count methods at interval of $2 \mathrm{~h}$ for $24 \mathrm{~h}$. To $200 \mathrm{ml}$ of Mueller Hinton broth in three conical flasks were added 400, 200 and $100 \mathrm{ml}$ of antiseptics to obtain 2, 1 and $0.5 \mathrm{v} / \mathrm{v}$ respectively. These solutions in flasks were seeded with $100 \mu \mathrm{l}$ of inoculum suspensions of test organism i.e. biofilm forming Pseudomonas aeruginosa $\left(1.5 \times 10^{8} \mathrm{cfu} / \mathrm{ml}\right)$ and incubated at $37{ }^{\circ} \mathrm{C}$ for 24h.The optical density of each dilution was recorded on UV/ spectrophotometer at 540nm (Jenway, 6405) at initiation time (0h) and every $2 \mathrm{~h}$ for $10 \mathrm{~h}$.

For surviving organism count, an aliquot of each dilution (1ml) was transferred and plated on $20 \mathrm{ml}$ Tryptic Soy agar at interval of $2 \mathrm{hrs}$. Plates were incubated at $37{ }^{\circ} \mathrm{C}$ for $24 \mathrm{~h}$. Number of viable organisms was counted as cfu/plates. Average duplicate ( 2 plates from each replicate dilution) counts were multiplied by the dilution factor to arrive at $\mathrm{cfu} / \mathrm{ml}$.

The result was statistically analyzed using a two-way analyses of variance (ANOVA) test with replicate was performed to evaluate any significant difference in mean absorbance values of various concentrations of disinfectants during time kill kinetics study. Differences were considered statistically significant at $\mathrm{P}<0.05$. The statistical variables were evaluated with SPSS version 21.0 window software while the obtained data were separated using Duncan new multiple range test.

\section{Result}

Time kill kinetics study of three most commonly used disinfectants namely Izal (Phenolic Compound), Savlon (Chlorhexidine cetrimide), and bleach (Hypochlorite) in Federal Medical Centre, Umuahia at concentrations of 0.5 XMBC, 1.0 XMBC and 2.0 XMBC 
against biofilm forming Pseudomonas aeruginosa isolates was determined and results presented in Table 1, 2 \& 3 and Figure 1. Izal (Phenol compound) at a concentration of $0.5 \mathrm{mg} / \mathrm{ml}$ and $1 \mathrm{mg} / \mathrm{ml}$ showed bacteriostatic activity against biofilm forming Pseudomonas aeruginosa isolates from initiation time up to $4 \mathrm{~h}$ (i.e. from $2.98 \times 10^{6}+5.773 \mathrm{c}$ to $2.90 \times 10^{6}+5.773 \mathrm{f}$ and from $4.0 \times 10^{6}+3.055$ a to $3.76 \times 10^{6}+5.774 \mathrm{~b}$ respectively), after which bacterial growth commenced. This indicates that the organism resisted the disinfectants just after $4 \mathrm{~h}$ of initiation time/application. The $2 \mathrm{mg} / \mathrm{ml}$ concentration of Izal (Phenol compound) achieved total lethality after $12 \mathrm{~h}$ (Table 2). For Savlon (chlorhexidine cetrimide), bacteriostatic effect was observed at concentrations of $0.5 \mathrm{mg} / \mathrm{ml}$ and $1 \mathrm{mg} / \mathrm{ml}$ from initiation time up to 8 h (i.e. from $3.0 \times 10^{6}+5.774$ to $3.02 \times 10^{6}+5.773 \mathrm{~b}$ and $4.2 \times 10^{6}+5.774$ a to $3.21 \times 10^{6}+5.773$ respectively).With concentration of $2 \mathrm{mg} / \mathrm{ml}$ of Savlon (chlorhexidine cetrimide), total lethality (bactericidal effect) was achieved after $10 \mathrm{~h}$ from initiation time (i.e. $4.5 \times 10^{6}+5.774$ a to $2.2 \times 10^{5}+5.773 \mathrm{~d}$ ) as shown in Table 3. At concentration of $2 \mathrm{mg} / \mathrm{ml}$, Bleach (Hypochlorite) showed outright lethality after $4 \mathrm{~h}$ of initiation time (i.e. from $4.2 \times 10^{6}+5.774 \mathrm{a}$ to $\left.3.90 \times 10^{5}+5.775\right)$ after which there remained no organism i.e. total eradication throughout the $24 \mathrm{~h}$ of incubation period (Table 4).

\begin{tabular}{|c|c|}
\hline Table 1: Disinfectants in Use at FMC Umuahia. \\
\hline Disinfectants & Chemical Composition \\
\hline (Brand name) & (Active ingredient) \\
\hline Izal & Phenolic Compound. \\
\hline Savlon & Chlorhexidine and Cetrimide. \\
\hline Bleach & Sodium hypochlorite \\
\hline Eposoxide & Hydrogen peroxide \\
\hline Z-germicide & Tar phenol and cresylic cresolate \\
\hline Methylated Spirit & Concentrated ethanol \\
\hline Dettol & Chloroxylenol (4-chloro-3,5-dimethylphenol) \\
\hline
\end{tabular}

Table 2: Time kill kinetics antibacterial study of Izal against biofilm forming Pseudomonas aeruginosa.

\begin{tabular}{|c|c|c|c|c|c|c|c|c|c|}
\hline Initiation Time & \multicolumn{3}{|c|}{ Population of Org. (cFu/ml) } & \multicolumn{2}{c|}{ Percentage (\%) Reduction } & \multicolumn{3}{c|}{ Log Reduction } \\
\hline & $\mathbf{0 . 5} \mathbf{m g} / \mathbf{m l}$ & $\mathbf{1} \mathbf{m g} / \mathbf{m l}$ & $\mathbf{2} \mathbf{m g} / \mathbf{m l}$ & $\begin{array}{c}\mathbf{0 . 5} \mathbf{m g} / \\
\mathbf{m l}\end{array}$ & $\begin{array}{c}\mathbf{1} \mathbf{m g} / \\
\mathbf{m l}\end{array}$ & $\begin{array}{c}\mathbf{2 m g} / \\
\mathbf{m l}\end{array}$ & $\begin{array}{c}\mathbf{0 . 5} \mathbf{m g} / \\
\mathbf{m l}\end{array}$ & $\begin{array}{c}\mathbf{1} \mathbf{m g} / \\
\mathbf{m l}\end{array}$ & $\begin{array}{c}\mathbf{2} \mathbf{m g} / \\
\mathbf{m l}\end{array}$ \\
\hline $\mathrm{Oh}$ & $2.98 \times 10^{6} \pm 5.773^{\mathrm{c}}$ & $4.0 \times 10^{6} \pm 3.055^{\mathrm{a}}$ & $4.40 \times 10^{6} \pm 5.774^{\mathrm{a}}$ & - & - & - & - & - & - \\
\hline 2 & $2.92 \times 10^{6} \pm 773^{\mathrm{e}}$ & $3.88 \times 10^{6} \pm 5.774^{\mathrm{ab}}$ & $2.98 \times 10^{5} \pm 5.774^{\mathrm{b}}$ & 2.01 & 2 & 34.27 & 0.009 & 0.013 & 0.169 \\
\hline 4 & $2.90 \times 10^{6} \pm 5.773^{\mathrm{f}}$ & $3.76 \times 10^{6} \pm 5.774^{\mathrm{b}}$ & $3.90 \times 10^{5} \pm 5.773^{\mathrm{c}}$ & 2.69 & 6 & 91.07 & 0.012 & 0.027 & 1.05 \\
\hline 6 & $2.91 \times 10^{6} \pm 5.773^{\mathrm{ef}}$ & $3.79 \times 10^{6} \pm 5.774^{\mathrm{ab}}$ & $2.60 \times 10^{5} \pm 5.773^{\mathrm{d}}$ & 2.35 & 5.25 & 94.09 & 0.01 & 0.023 & 1.228 \\
\hline 8 & $2.96 \times 10^{6} \pm 5.773^{\mathrm{d}}$ & $3.84 \times 10^{6} \pm 5.774^{\mathrm{ab}}$ & $2.4 \times 10^{5} \pm 5.773^{\mathrm{d}}$ & 0.67 & 4 & 95.23 & 0.003 & 0.018 & 1.321 \\
\hline 10 & $2.97 \times 10^{6} \pm 5.773^{\mathrm{c}}$ & $3.88 \times 10^{6} \pm 5.774^{\mathrm{ab}}$ & $2.4 \times 10^{5} \pm 5.773^{\mathrm{d}}$ & -0.34 & 3 & 95.23 & -0.001 & 0.013 & 1.321 \\
\hline 12 & $2.98 \times 10^{6} \pm 5.773^{\mathrm{b}}$ & $3.92 \times 10^{6} \pm 5.774^{\mathrm{ab}}$ & $2.4 \times 10^{5} \pm 5.773^{\mathrm{d}}$ & -4.7 & 2 & 95.23 & -0.01 & 0.009 & 1.321 \\
\hline 24 & $2.9 \times 10^{6} \pm 5.773^{\mathrm{a}}$ & $3.97 \times 10^{6} \pm 5.774^{\mathrm{a}}$ & 0 & -12.08 & 0.75 & 100 & -0.05 & 0.003 & 6.643 \\
\hline
\end{tabular}

Key Values are means \pm standard error of means of three replicates. Values in each column followed by different superscript within each column are significantly different at $\mathrm{P}=0.05$

\begin{tabular}{|c|c|c|c|c|c|c|c|c|c|}
\hline \multicolumn{2}{|c|}{ Table 3: Time kill kinetics antibacterial study of Savlon against biofilm forming Pseudomonas aeruginosa. } \\
\hline Initiation Time & \multicolumn{2}{|c|}{ Population of Org. (cFu/ml) } & \multicolumn{2}{c|}{ Percentage (\%) Reduction } & \multicolumn{3}{c|}{ Log Reduction } \\
\hline $\mathbf{H r}$ & $\mathbf{0 . 5} \mathbf{m g} / \mathbf{m l}$ & $\mathbf{1} \mathbf{m g} / \mathbf{m l}$ & $\mathbf{2} \mathbf{m g} / \mathbf{m l}$ & $\mathbf{0 . 5} \mathbf{m g} / \mathbf{m l}$ & $\begin{array}{c}\mathbf{m g} / \\
\mathbf{m l}\end{array}$ & $\begin{array}{c}\mathbf{2} \mathbf{m g} / \\
\mathbf{m l}\end{array}$ & $\begin{array}{c}\mathbf{0 . 5} \mathbf{m g} / \\
\mathbf{m l}\end{array}$ & $\begin{array}{c}\mathbf{1} \mathbf{m g} / \\
\mathbf{m l}\end{array}$ & $\begin{array}{c}\mathbf{2} \mathbf{m g} / \\
\mathbf{m l}\end{array}$ \\
\hline $\mathrm{Ohr}$ & $3.0 \times 10^{6} \pm 5.774$ & $4.2 \times 10^{6} \pm 5.774^{\mathrm{a}}$ & $4.5 \times 10^{6} \pm 5.774^{\mathrm{a}}$ & - & - & - & - & - & - \\
\hline 2 & $2.962 \times 10^{6} \pm 773^{\mathrm{bc}}$ & $3.99 \times 10^{6} \pm 5.773^{\mathrm{b}}$ & $3.0 \times 10^{5} \pm 5.773^{\mathrm{b}}$ & 1.33 & 500 & 33.33 & 0.006 & 0.022 & 0.0176 \\
\hline 4 & $2.87 \times 10^{6} \pm 3.512^{\mathrm{d}}$ & $3.42 \times 10^{6} \pm 5.77^{\mathrm{d}}$ & $3.90 \times 10^{5} \pm 5.773^{\mathrm{c}}$ & 3.33 & 18.57 & 91.22 & 0.015 & 0.089 & 1.157 \\
\hline 6 & $2.92 \times 10^{6} \pm 5.773^{\mathrm{ad}}$ & $3.00 \times 10^{6} \pm 5.774^{\mathrm{f}}$ & $2.70 \times 10^{5} \pm 5.773^{\mathrm{d}}$ & 2.67 & 28.57 & 94 & 0.012 & 0.146 & 1.322 \\
\hline 8 & $3.02 \times 10^{6} \pm 5.773^{\mathrm{b}}$ & $3.21 \times 10^{6} \pm 5.773^{\mathrm{e}}$ & $2.2 \times 10^{5} \pm 5.773^{\mathrm{d}}$ & -0.67 & 23.57 & 95.11 & -0.003 & 0.117 & 1.411 \\
\hline 10 & $3.24 \times 10^{6} \pm 5.773^{\mathrm{a}}$ & $3.46 \times 10^{6} \pm 5.773^{\mathrm{cd}}$ & $2.2 \times 10^{5} \pm 5.773^{\mathrm{d}}$ & -8 & 17.62 & 95.11 & -0.033 & 0.084 & 2.311 \\
\hline
\end{tabular}




\begin{tabular}{|c|c|c|c|c|c|c|c|c|c|}
\hline 12 & $3.27 \times 10^{6} \pm 3.512^{\mathrm{a}}$ & $3.51 \times 10^{6} \pm 5.773^{\text {cd }}$ & 0 & -10 & 16.43 & 100 & -0.041 & 0.078 & 6.252 \\
\hline 24 & $3.22 \times 10^{6} \pm 5.773^{\mathrm{a}}$ & $3.55 \times 10^{6} \pm 5.773^{c}$ & 0 & -7.33 & 15.48 & 100 & -0.031 & 0.073 & 6.252 \\
\hline
\end{tabular}

Key: Values are means \pm standard error of means of three replicates. Values in each column followed by different superscript within each column are significantly different at $\mathrm{P}=0.05$.

\begin{tabular}{|c|c|c|c|c|c|c|c|c|c|}
\hline \multirow{2}{*}{$\begin{array}{l}\text { Initiation } \\
\text { Time }\end{array}$} & \multicolumn{3}{|c|}{ Population of Org. (cFu/ml) } & \multicolumn{3}{|c|}{ Percentage (\%) Reduction } & \multicolumn{3}{|c|}{ Log Reduction } \\
\hline & $0.5 \mathrm{mg} / \mathrm{ml}$ & $1 \mathrm{mg} / \mathrm{ml}$ & $2 \mathrm{mg} / \mathrm{ml}$ & $0.5 \mathrm{mg} / \mathrm{ml}$ & $1 \mathrm{mg} / \mathrm{ml}$ & $2 \mathrm{mg} / \mathrm{ml}$ & $\begin{array}{c}0.5 \mathrm{mg} / \\
\mathrm{ml}\end{array}$ & $1 \mathrm{mg} / \mathrm{ml}$ & $2 \mathrm{mg} / \mathrm{ml}$ \\
\hline $\mathrm{Oh}$ & $2.92 \times 10^{6} \pm 5.774^{\mathrm{e}}$ & $3.62 \times 10^{6} \pm 5.055^{\mathrm{a}}$ & $4.2 \times 10^{6} \pm 5.774^{\mathrm{a}}$ & - & - & - & - & - & - \\
\hline 2 & $2.90 \times 10^{6} \pm 774^{\mathrm{f}}$ & $3.61 \times 10^{6} \pm 5.774^{\mathrm{a}}$ & $2.0 \times 10^{6} \pm 5.773^{b}$ & 68 & 0.28 & 52.33 & 0.003 & 0.001 & 0.322 \\
\hline 4 & $2.93 \times 10^{6} \pm 5.774^{\mathrm{e}}$ & $2.99 \times 10^{6} \pm 5.77^{e}$ & $3.90 \times 10^{5} \pm 5.775$ & -0.34 & 17.4 & 90.19 & -0.001 & 0.083 & 1.032 \\
\hline 6 & $2.98 \times 10^{6} \pm 5.774^{\mathrm{d}}$ & $3.01 \times 10^{6} \pm 5.774^{\mathrm{e}}$ & 0 & -2.05 & 16.85 & 100 & -0.009 & 0.08 & 6.623 \\
\hline 8 & $3.00 \times 10^{6} \pm 774^{c}$ & $3.10 \times 10^{6} \pm 5.774^{\mathrm{d}}$ & 0 & -2.74 & 14.36 & 100 & -0.012 & 0.067 & 6.623 \\
\hline 10 & $3.02 \times 10^{6} \pm 774^{b}$ & $3.30 \times 10^{6} \pm 5.774^{c}$ & 0 & -3.42 & 11.6 & 100 & -0.015 & 0.054 & 6.623 \\
\hline 12 & $3.20 \times 10^{6} \pm 5.774^{\mathrm{a}}$ & $3.21 \times 10^{6} \pm 5.774^{c}$ & 0 & -9.59 & 11.33 & 100 & -0.04 & 0.052 & 6.623 \\
\hline 24 & $3.21 \times 10^{6} \pm 5.774^{\mathrm{a}}$ & $3.30 \times 10^{6} \pm 5.774^{b}$ & 0 & -9.93 & 8.84 & 100 & -0.041 & 0.04 & 6.623 \\
\hline
\end{tabular}

Key Values are means \pm standard error of means of three replicates. Values in each column followed by different superscript within each column are significantly different at $\mathrm{P}=0.05$.

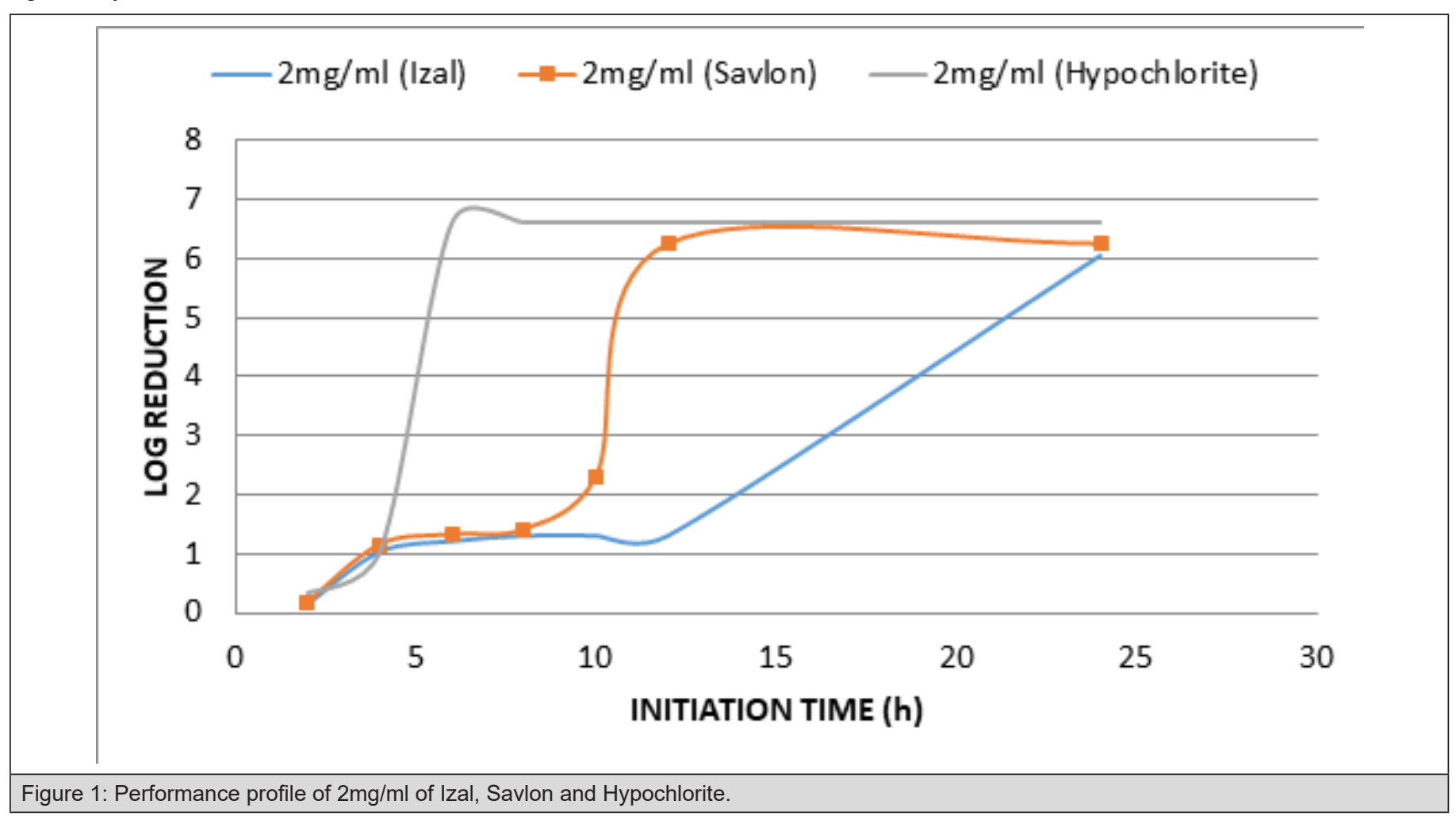

\section{Discussion}

Increases in the incidence of multidrug-resistant and biofilm forming Pseudomonas aeruginosa infections as nosocomial etiological agents have prompted renewed efforts to identify biologically and chemically active molecules from both natural and synthetic sources that might be useful antibacterial agents for disinfection. Several Cordyceps species extracts, including those from $C$. sinen- sis [32] have been identified as biologically active agents that can eradicate nosocomial pathogens. Some of these agents have been reported to have potent antibacterial activity against human pathogenic bacteria specifically [33]. Time-kill kinetics antibacterial study has been used to investigate numerous antimicrobial agents and they are also often used as the basis for invitro investigation for pharmacodynamic drug interactions [34]. Recently, several studies 
have reported antibacterial activities of extracts or essential oils of T. daenensis while few concentrated on synthetic chemicals [35].

The time kill antibacterial assay of these disinfectants gave variable kinetics against susceptible biofilm forming Pseusomonas aeruginosa tested as seen in Tables 2-4. These disinfectants demonstrated both bacteriostatic and bactericidal effects as it shows a concentration dependent killing. The bactericidal concentration of these disinfectant agents against biofilm forming Pseusomonas aeruginosa is not surprising as this organism has been reported to be resistant to many antimicrobial agents [36]. However bacteriostatic effect was observed at a lower concentration $(0.5 \mathrm{mg} / \mathrm{ml}$ and $1.0 \mathrm{mg} / \mathrm{ml}$ ). Overall, this time-kill study corroborates the reported efficacies of some preliminary antibacterial study of selected plant extract as reported by Oladosu et al. [37] which proves their folkloric uses in treatment of different ailments among the traditional people.

In this study, the susceptibility of biofilm forming Pseudomonas aeruginosa to commonly used disinfectants were firstly determined by the disc diffusion method as described by WHO in 2003 [38] while minimum inhibitory concentration (MIC) and minimum bactericidal concentration (MBC) was determined using the methods described by Turnidge et al. [39]. This study also quantified the antibacterial effect of these disinfectants through an automated, chromogenic endpoint assay, ensuring that the turbidity of the disinfectant was excluded from that of the bacterial growth.

The time-kill data obtained in this study based on the effect of the three biocides on biofilm forming Pseudomonas aerugino$s a$ showed their antibacterial activity to be time - and concentration-dependent. This finding correlates with that of Okemo et al. [40] who found that Ximenia caffra extracts kill $S$. aureus in both a time- and concentration-dependent manner. The time-kill kinetics antibacterial study of these antiseptics was done according to standard guide for assessment of antimicrobial activity using time-kill kinetics procedure of Antimicrobial Susceptibility Testing Method [31]. Microbial population at the initiation and completion was determined by spectrometric and plate count methods at interval of $2 \mathrm{~h}$.

\section{Conclusion}

All the three biocides were not efficient in eradicating biofilm forming Pseudomonas aeruginosa satisfactorily at concentrations of 0.5 and $1.0 \mathrm{mg} / \mathrm{ml}$. However, at $2 \mathrm{mg} / \mathrm{ml}$, lethality was achieved by all of them at different time. Bleach (Hypochlorite) is the most efficacious disinfectant in use in Federal Medical Center Umuahia having demonstrated maximum lethality (maximum bactericidal effect) at a shorter time of $4 \mathrm{~h}$ than Savlon (chlorhexidine cetrimide), $8 \mathrm{~h}$ and Izal (Phenol compound), 12h. Although Izal (Phenol compound) was not the most effective of the three, there was steady sustenance of bactericidal and bacteriostatic activity by Izal
(Phenol compound) for a very long period compared to others as seen in Figure 1.

\section{Acknowledgment}

We acknowledge the support received from the Management and Ethics and Research committee of Federal Medical Centre, Umuahia, Southeast Nigeria for the privilege to use the institution`s facility during our field work.

\section{Contribution of Authors}

The authors declare that this work was done by the authors named in this article and all liabilities pertaining to claims relating to the content of this article will be borne by them.

\section{References}

1. Bell M (2011) Biofilms: A clinical perspective. Curr Infect Dis Rep 3(6): 483-486.

2. Vernon MO, Hayden MK, Trick WE, Hayes RA, Blom DW, et al. (2006) Chlorhexidine gluconate to cleanse patients in a Medical Intensive Care Unit. Arch Intern Med 166(3): 306-312.

3. Livornese LL, Dias S, Samel C, Romanowski B, Taylor S, et al. (1992) Hospital-acquired infection with vancomycin-resistant Enterococcus faecium transmitted by electronic thermometers. Ann Intern Med 117(2): 112-126.

4. Brooks S, Khan A, Stoica D, Griffith J, Friedman L, et al. (1998) Reduction in vancomycin-resistant Enterococcus and Clostridium difficile infections following change to tympanic thermometers. Infect Control Hosp Epidemiol 19(5): 333-336.

5. Sebastian A, Larsson L (2003) Characterization of the microbial community in indoor 'environments: A chemical-analytical Approach. Appl Environ Microbiol 69(6): 3103- 3109.

6. Rutala WA, Weber DJ (2008) The Healthcare Infection Control Practices Advisory Committee (HICPAC) Guideline for disinfection and sterilization in healthcare facilities. Atlanta CDC report 9: 23-46.

7. Martínez JA, Ruthazer R, Hansjosten K, Barefoot L, Snydman DR (2003) Role of environmental contamination as a risk factor for acquisition of vancomycin-resistant enterococci in patients treated in a Medical intensive care unit. Arch Intern Med 163(16): 1905-1912.

8. WHO (2011) Report on the burden of endemic healthcare associated infection worldwide. WHO Annual report (1): 1-34.

9. Théraud M, Bédouin Y, Guiguen C, Gangneux JP (2004) Efficacy of antiseptics and disinfectants on clinical and environmental yeast isolates in planktonic and biofilm. Journal of Medical Microbiology 53, 1013-1018.

10. Russel AD (2003) Similarities and differences in the responses of microorganisms to biocides. J Antimicrob Chemother 52(5): 750-763.

11. Cloete TE, Westaard D, van Vuuren SJ (2010) Dynamic response of biofilm to pipe surface and fluid velocity. Water Sci Technol 47(5): 57-59.

12. Ogbulie JN, Adieze IE, Nwankwo NC (2008) Susceptibility pattern of some clinical bacterial isolate to selected antibiotic and disinfectants. Pol J Microbiol 57(3): 199-204.

13. Romão CM, Faria YN, Pereira LR, Asensi MD (2005) Susceptibility of clinical isolates of multi-resistant Pseudomonas aeruginosa to a hospital disinfectant and molecular typing. Mem Inst Oswaldo Cruz 100(5): 541548.

14. WHO (2004) Practical guidelines for infection control in health care facilities. SEARO Regional Publication No. 41 WPRO Regional Publication. 
15. Mcdonnell G, Russell D (1999) Antiseptics and Disinfectants: Activity, Action, and Resistance. Clin Microbiol Rev 12(1): 147-179.

16. CDC (2008) Guideline for Disinfection and Sterilization in Healthcare Facilities. Accessed on $2^{\text {nd }}$ December, 2019.

17. Carling PC, Huang SS (2013) Improving healthcare environmental cleaning and disinfection: current and evolving issues. Infect Control Hosp Epidemiol 34(5): 507-513.

18. Havill NL, Havill HL, Mangione E, Dumigan DG, Boyce JM (2011) Cleanliness of portable medical equipment disinfected by nursing staff. Am J Infect Control 39(7): 602-604.

19. Huang SS, Datta R, Platt R (2006) Risk of acquiring antibiotic-resistant bacteria from previous room occupants. Arch Intern Med 166(18): 1945-1951.

20. Nseir S, Blazejewski C, Lubret R, Wallet F, Courcol R, et al. (2011) Risk of acquiring multi drug-resistant Gram-negative bacilli from prior room occupants in the intensive care unit. Clin Microbiol Infect 17:1201-1208.

21. Ozdemir HO, Buzoglu HD, Calt S, Stabholz A, Steinberg D (2010) Effect of ethylenediaminetetra-acctic acid and sodium hypochloride irrigation on Entercoccus faecalis biofilm colonization in young and old human root canal dentin: in vitro study. Journal of Endodontics, 36(5): 842-846.

22. Araújo P, Lemos M, Mergulhão F, Melo L, Simões M (2011) Antimicrobial resistance to ' disinfectants in biofilms, Science against microbial pathogens: communicating current research and technological advances 8: 826-834.

23. Lomander A, Schreuders P, Russeth-Cohen E, Ali L (2004) Evaluation of chlorine impact of mofilms on scratched stainless-steel surfaces. Bioresour Technol 94(3): 275-283.

24. de Carvalho CC (2007) Biofilms- recent developments on an old battle. Recent Pat Biotechnol 1(1): 49-57.

25. Toté K, Horemans T, Vanden Berghe D, Maes L, Cos P (2010) Inhibitory effect of biocides on the viable masses and matrices of Staphylococcus aureus and Pseudomonas aeruginosa biofilms. Appl Environ Microbiol 76(10): 3135-3142.

26. Kim, TJ, Siiva JL, Chamul RS, Chen (2000) Influence of ozone, hydrogen peroxide, or sail: on microbial profile, Tbars and colon of channel catfish fillers. Journal of Food Science 65(7): 1841 -1847.

27. Pascual A, Liorca, I, Canut A (2007) Use of ozone in food industries for reducing the environmental impact of cleaning and disinfection activities. Trends in Food Science and Technology 18(Suppl 1): 529-535.

28. Tachikawa M, Yamanaka K, Nakamuna K (2009) Studies on the disinfection and removal of biofilms by ozone water using an artificial microbial biofilms system. Ozone: Science and Engineering 31(1): 3-9.
29. Jorgensen JH, Ferraro MJ (2009) Antimicrobial Susceptibility Testing: A Review of General Principles and Contemporary Practices. Clin Infect Dis 49(11): 1749-1755.

30. Sutthiwan Thammawat, Kusavadee Sangdee, Aphidech Sangdee (2017) Time-kill profiles and cell-surface morphological effects of crude Polycephalomyces nipponicus Cod-MK1201 mycelial extract against antibiotic-sensitive and -resistant Staphylococcus aureus. Tropical Journal of Pharmaceutical Research 16(2): 407-412.

31. CLSI (2007) Performance standards for antimicrobial disc susceptibility test; approved standard $9^{\text {th }}$ edition. Clinical and Laboratory Standard Institute (CLSI) document 3: M2-M9.

32. Hu Zheng, Ye Maoqing, Xia Liqiu, Tu Wenjuan, Li Liang, et al. (2006) Purification and characterization of an antibacterial protein from the cultured mycelia of Cordyceps sinensis. Wuhan University J Nat Sci 11:709-714.

33. Xiao JH, Xiao DM, Sun ZH, Xiong Q, Liang ZQ, et al. (2009) Chemical compositions and antimicrobial property of three edible and medicinal Cordyceps species. J Food Agric Environ 7(3-4): 91-100.

34. Ogunwonyi IH, Ntsikelelo M, Leonard M, Elvis N, Ezekiel G, et al. (2010) In vitro time kill studies of antibacterial agent from putativemarine Streptomyces species isolated from the Nahoo beach South Africa. African Journal of pharm Pharmacol 4(12): 908-916.

35. Sharareh R, Samaneh A, Hamid R (2016) Time-kill kinetics and antibacterial activity of crude methanolic extract of Thymus daenensis Celak. An International Journal of Medical Sciences 27: 975-1083

36. Orishadipe AT (2005) Phytochemical and antimicrobial properties of leaf extracts of Entadrophragmaanglensis (WELW). Ph.D Thesis, University of Ibadan, Nigeria.

37. Oladosu P, Isu NR, Ibrahim K, Ibrahim JA (2010) Ethno-botancal survey and preliminary evaluation of some selected medicinal plants used in the treatment of tuberculosis in some parts of Northern Nigeria. ZUMA J Appl Sci 8: 1-4.

38. World Health Organization (2003) Laboratory identification and antimicrobial susceptibility testing of bacterial pathogens of public health importance in the developing world. WHO Mammal 20: 34-39.

39. Turnidge JD, Ferraro MJ, Jorgensen JH (2003) Manual of Clinical Microbiology. ( $8^{\text {th }}$ edn), Washington, USA. American Society of Clinical Microbiology, p.1103

40. Okemo PO, Mwatha WE, Chhabra SC (2004) The kill kinetics of Ximenia caffra sond. (Olacaceae) extracts against selected bacteria and fungi. J Trop Microbiol Biotechno 3(1): 88-94. 